\title{
Silencing of ataxia-telangiectasia mutated by siRNA enhances the in vitro and in vivo radiosensitivity of glioma
}

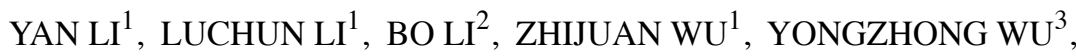 \\ YING WANG $^{3}$, FU JIN ${ }^{3}$, DAIRONG LI ${ }^{1}$, HUIWEN MA ${ }^{1}$ and DONGLIN WANG ${ }^{1}$ \\ ${ }^{1}$ Department of Oncology, Chongqing Cancer Institute, Chongqing 400030; \\ ${ }^{2}$ Department of Orthopaedics, The First People's Hospital, Jiangbei, Chongqing 400020; \\ ${ }^{3}$ Department of Radiotherapy, Chongqing Cancer Institute, Chongqing 400030, P.R. China
}

Received December 8, 2015; Accepted January 4, 2016

DOI: $10.3892 /$ or.2016.4754

\begin{abstract}
It is reported that high expression of the ataxia-telangiectasia mutated (ATM) gene is linked with radioresistance in glioma. We hypothesized that the radiosensitivity of this brain tumor is enhanced by silencing of the ATM gene. We transfected the glioma cell line U251 with the siRNA-ATM ${ }^{\text {puro }}$ (group A) lentivirus or the siRNA-HK ${ }^{\text {puro }}$ (group N, negative control) lentivirus before irradiation. RT-qPCR and western blotting were performed to verify the efficiency of siRNA-mediated ATM silencing. Expression levels of the ATM gene and protein were obviously downregulated after transfection. Moreover, the expression of the p53, PCNA and survivin genes, which are related to radiosensitivity, was also decreased. CCK-8 and colony formation assays showed lower cell proliferation and survival in group $\mathrm{A}$ than in groups $\mathrm{N}$ and $\mathrm{C}$ (control group that was not transfected with any siRNA). The level of double-stranded DNA breaks was also greater in group A, as determined by the comet tail assay. Flow cytometry showed a higher rate of cell apoptosis and a higher number of cells in the G2 phase in group A. Furthermore, caspase-3, caspase- 8 and caspase-9 activity was also higher in group A. In vivo analysis in mouse models created by implantation of the transfected cell lines showed that the amount of necrosis and hemorrhage was higher in group A than that in the control groups. In conclusion, silencing of ATM via the siRNA technique could improve the in vitro and in vivo radiosensitivity of glioma cells.
\end{abstract}

\section{Introduction}

Glioma is a malignant brain tumor associated with poor prognosis and a median survival period of only $12-15$ months $(1,2)$.

Correspondence to: Dr Donglin Wang, Department of Oncology, Chongqing Cancer Institute, Chongqing 400030, P.R. China

E-mail: xiaolianbei@sina.com

Key words: glioma, ataxia-telangiectasia mutated, siRNA, animal model, radiosensitivity
Unfortunately, gliomas can be resistant to irradiation and chemotherapy, and surgical resection is sometimes difficult. Thus, more effective treatment strategies are required to manage this malignancy and improve the survival rate of patients.

It is well known that ataxia-telangiectasia mutated (ATM) is a proximal component of DNA damage-induced cell cycle checkpoint pathways (3-5). It is believed that the ATM gene plays a role in blocking the cell cycle in order to protect cells from damage caused by irradiation and provide enough time for self-repair $(2,6,7)$. Many laboratories have verified that overexpression of the ATM gene in gliomas is linked with the radioresistance of these tumors (1,8-10). Therefore, strategies that suppress ATM gene expression may improve the radiosensitivity of malignant gliomas. At present, pharmacological and genetic methods are used to repress the expression of ATM. For example, Guha et al (11) found that attenuated ATM protein expression via antisense-ATM could increase radiosensitivity in U87 cells. Chuah et al (12) employed and compared three different viral vectors (retrovirus, adenovirus, and lentivirus) to deliver the siRNA-ATM plasmid, and found that radiosensitivity of the glioma cell line was obviously enhanced after suppression of ATM expression. Furthermore, they reported that the lentivirus system was the most efficient with regard to transfection and suppression of the ATM gene. Nadkarni et al (13) reported that after inhibition of the ATM kinase KU55933 in glioma cells, expression levels of the genes related to radiosensitization (ATM and p53) and the cell cycle (p21) were significantly decreased, and proliferation of cells in the G2 phase was blocked. In recent years, KU60019, a new ATM kinase inhibitor, was found to have good potential with regard to increase in tumor cell apoptosis and repression of tumor growth in gliomas $(1,7)$. However, the optimal dose and mode of administration of ATM kinase inhibitors are not clear (7). Moreover, inhibitors are usually short acting and therefore cannot permanently and stably repress ATM gene expression. Therefore, there is a need for more effective inhibitors and gene interference strategies that can ensure long-term stable ATM silencing.

To date, few studies have been conducted on the radiosensitivity of glioma cells after ATM gene interference or silencing. Some scholars have reported that siRNA against ATM could 
improve the effect of radiotherapy in glioma cell lines $(11,12)$. These were in vitro studies conducted on different cell lines and under different experimental conditions, thus the siRNA strategy needs to be explored under in vivo conditions.

In our study, we induced silencing of the ATM gene using the siRNA technique and then explored its effect on the in vivo and in vitro radiosensitivity of gliomas. To the best of our knowledge, there is less research on in vivo silencing of the ATM gene. We therefore believe that the contributions of this study will be extremely valuable with regard to establishing treatment strategies for this tumor.

\section{Materials and methods}

Cell line and culture. The human glioma cell line U251 was used; it was gifted by the Central Laboratory of the Oncology Department of Xinqiao Hospital of the Third Military Medical University. The cell line was cultured in RPMI-1640 medium supplemented with $10 \%$ fetal calf serum (FCS) (both from Gibco, Grand Island, NY, USA), $100 \mathrm{U} / \mathrm{ml}$ penicillin, $100 \mu \mathrm{g} / \mathrm{ml}$ streptomycin, $2 \mathrm{mM}$ glutamine, and $1 \mathrm{mM}$ sodium pyruvate. The cells were cultured in humidified incubators at $37^{\circ} \mathrm{C}$ in an atmosphere containing $5 \% \mathrm{CO}_{2}$. The cells were maintained as a monolayer by serial passaging after trypsinization with $0.1 \%$ trypsin (Gibco).

Animals. Four-week-old male Balb/c-nu/nu mice weighing 20-23 g were purchased from the Shanghai Experimental Animal Center of the Chinese Academy of Medical Sciences, China. They were kept in cages and supplied with food and water ad libitum in a pathogen-free environment at a temperature of $25-27^{\circ} \mathrm{C}$ and humidity of $45-50 \%$. All the animals received humane care according to the institutional policies on Human Care and Use of Laboratory Animals and with the approval of the Ethics Committee of Chongqing Cancer Institute.

Cell transfection and in vitro radiation treatment. The cell line was seeded at a density of $2 \times 10^{5}$ cells/well in 6 -well plates and cultured overnight. After $48 \mathrm{~h}$ of incubation, $40 \mu \mathrm{l}$ (MOI=2) of siRNA-ATM ${ }^{\text {Puro }}$ or siRNA-HK ${ }^{\text {Puro }}$ lentivirus (Hanheng Bio Co., Ltd., Shanghai, China) was added to the wells when the cells had reached a confluency of $30-40 \%$. Then, serum-free medium was added to 6 -well plates for $24 \mathrm{~h}$ of co-culture. The efficiency of transfection into tumor cells was observed under an inverted fluorescence microscope, and resistant target cells were selected by treatment with puromycin until a stable cell line transfected with the lentivirus was successfully established.

Three groups were created for the in vitro experiments: the blank control group C (U251 cells were not transfected with siRNA), the negative control group N (U251 cells were transfected with siRNA-HK ${ }^{\text {Puro }}$, and the experimental group A (U251 cells were transfected with siRNA-ATM ${ }^{\text {Puro }}$ ). The cells from the three groups were irradiated using a 6-MV X Rad source (SN4474, Varian) to deliver doses of 2, 4, 5, 6 and $8 \mathrm{~Gy}$. The dose rate was $300 \mathrm{cGy} / \mathrm{min}$. The cells were harvested after irradiation for different time periods: cells for RT-qPCR and western blotting were harvested $24 \mathrm{~h}$ after irradiation; cells for the comet assay were harvested after $4 \mathrm{~h}$; and cells for flow cytometric analysis were harvested after $24 \mathrm{~h}$.
Animal model and in vivo radiation treatment. U251 cells transfected with siRNA-ATM ${ }^{\text {Puro }}$ or siRNA-HK ${ }^{\text {Puro }}$ were collected at the log phase and injected into each side of the same mouse's haunch. Two weeks later, the tumor reached a volume of $2.0 \times 1.8 \times 1.0 \mathrm{~cm}$, which indicated that the model was successfully established.

The mice from each group (siRNA-ATM ${ }^{\text {Puro }}$ and siRNA-HK ${ }^{\text {Puro }}$ ) were divided into two subgroups of three animals each after subcutaneous implantation: the irradiation group and the radiation-free group. The model mice from the two radiation subgroups $(\mathrm{n}=6)$ were administered ketamine $(10 \mathrm{ml} / \mathrm{kg})$ and fixed in the ventricumbent position. The subcutaneous tumor was thereafter irradiated locally with ionizing radiation under a 6-MV linear accelerator. The parameters for radiotherapy were as follows: target range, $100 \mathrm{~cm}$; dose rate, $300 \mathrm{MU} / \mathrm{min}$; total dose (TD), 1,500 cGy. Changes in tumor volume were examined within one to four weeks after irradiation, and the corresponding growth curve was drawn. All the mice were sacrificed after 4 weeks to harvest the tumor for histopathological examination. The samples were fixed in $10 \%$ formalin to create paraffin sections, and stained with hematoxylin and eosin for microscopic examination.

RNA isolation and reverse transcription. Total RNA of the U251 cell line was extracted using TRIzol (Sigma, Milwaukee, WI, USA). Concentration and purity were assessed using an ultraviolet spectrophotometer at a wavelength of 260 and $280 \mathrm{~nm}$. RNA was reverse transcribed into cDNA using the reverse transcription kit (Takara Bio, Dalian, China). A master mix (20 $\mu \mathrm{l}$ in total) containing $2 \mathrm{X}$ RT buffer $(10 \mu \mathrm{l})$, RT mix (1 $\mu \mathrm{l})$, $6 \mathrm{~N}$ random primers $(1 \mu \mathrm{l})$, total RNA $(5 \mu \mathrm{l})$, and nuclease-free water $(3 \mu \mathrm{l})$ was prepared on ice. The reaction was performed at $25^{\circ} \mathrm{C}$ for $10 \mathrm{~min}, 42^{\circ} \mathrm{C}$ for $50 \mathrm{~min}$, and finally at $85^{\circ} \mathrm{C}$ for $5 \mathrm{~min}$.

$R T$ - $q P C R$. cDNA from the U251 glioma cell line was subjected to RT-qPCR, which was performed using the IQ5 PCR instrument and the SYBR Green real-time PCR Master Mix kit (Takara Bio). For amplification of ATM, a Master Mix $(50 \mu \mathrm{l})$ was prepared on ice with $25.5 \mu \mathrm{l}$ SYBR Green I Master Mix, $1 \mu \mathrm{l}$ of each primer, $2 \mu \mathrm{l}$ cDNA, and $20.5 \mu \mathrm{l}$ nuclease-free water. The cDNA was initially denatured at $94^{\circ} \mathrm{C}$ for 4 min followed by 35 cycles of denaturation at $94^{\circ} \mathrm{C}$ for $20 \mathrm{sec}$, annealing at $60^{\circ} \mathrm{C}$ for $30 \mathrm{sec}$, and extension at $72^{\circ} \mathrm{C}$ for $30 \mathrm{sec}$. For amplification of p53, PCNA and survivin, a Master Mix (25 $\mu \mathrm{l})$ containing $10 \mu \mathrm{l}$ SYBR Green I Master Mix, $1 \mu \mathrm{l}$ of each primer, $5 \mu \mathrm{l}$ of cDNA, and $8 \mu 1$ nuclease-free water was prepared on ice. After the cDNA was denatured at $94^{\circ} \mathrm{C}$ for $4 \mathrm{~min}, 40$ cycles of denaturation at $95^{\circ} \mathrm{C}$ for $5 \mathrm{sec}$, annealing at $60^{\circ} \mathrm{C}$ for $30 \mathrm{sec}$, and extension at $72^{\circ} \mathrm{C}$ for $40 \mathrm{sec}$ were performed. Primer sequences were designed using the software Primer 5.0, and the sequences used are listed in Table I. Actin was used as an endogenous control. All the experiments were performed in triplicate. The specificity of the amplification instructions and absence of primer dimers were confirmed through a melting curve analysis for each run. Relative quantification of the expression of all genes was performed using the $2^{-\Delta \Delta \mathrm{Ct}}$ method.

Western blotting. U251 cells were harvested on ice, and the total protein extraction kit containing protease inhibitor 
Table I. Sequences of the primers used for RT-qPCR.

\begin{tabular}{|c|c|c|c|c|}
\hline \multirow{2}{*}{$\frac{\text { Gene }}{\text { Actin }}$} & \multicolumn{2}{|c|}{ Primer sequences } & \multirow{2}{*}{$\begin{array}{c}\begin{array}{c}\text { Annealing } \\
\text { temperature } \\
\left({ }^{\circ} \mathrm{C}\right)\end{array} \\
60\end{array}$} & \multirow{2}{*}{$\begin{array}{c}\begin{array}{c}\text { Product } \\
\text { length } \\
(\mathrm{bp})\end{array} \\
205\end{array}$} \\
\hline & F: 5'-TGACGTGGACATCCGCAAAG-3' & R: 5'-CTGGAAGGTGGACAGCGAGG-3' & & \\
\hline ATM & F: 5'-GCACAGAAGTGCCTCCAATTC-3' & R: 5'-ACATTCTGGCACGCTTTGG-3' & 60 & 125 \\
\hline P53 & F: 5'-CAGTCTACCTCCCGCCATAA-3' & R: 5'-GTTCAAAGACCCAAAACCCA-3' & 57 & 144 \\
\hline PCNA & F: 5'-GGGACACTGCTGGTGGTATT-3' & R: 5'-ACTGGTGGAGGGTAAACGGA-3' & 59 & 102 \\
\hline Survivin & F: 5'-TGTGATGAGGACAAAACGAAGC-3' & R: 5'-CAGCCTGAGCAACAGAGCAA-3' & 59 & 100 \\
\hline
\end{tabular}

F, forward; R, reverse.

was used. Total protein from U251 cells was extracted after homogenization. The protein concentration was determined using Coomassie brilliant blue staining. Subsequently, $10 \%$ SDS-PAGE was performed to separate the proteins (50 mg of protein per sample), and the extracted proteins were transferred onto a polyvinylidene fluoride (PVDF) membrane. The membrane was incubated overnight with the primary antibodies diluted to 1:1,000 (5\% w/v-BSA/TBST), and then incubated with the secondary antibodies diluted to 1:1,000 (Zhongshan Biotechnology). Next, the treated membrane was used for film development and further analysis. The primary antibodies used were anti-ATM and anti-phos-ATM (S1981) antibodies (Santa Cruz Biotechnology Inc., Santa Cruz, CA, USA).

Cell counting. After irradiation, the ability for cell proliferation was determined in triplicate using the CCK-8 assay (Dojindo, Japan). Malignant cells, including those transfected with siRNA-ATM ${ }^{\text {Puro }}$ or siRNA-HK ${ }^{\text {Puro }}$, were plated onto 96-well plates at a concentration of 3,000 per well and cultured at $37^{\circ} \mathrm{C}$ overnight. Thereafter, the cells were incubated with $10 \mu \mathrm{l} \mathrm{CCK}-8$ for $4 \mathrm{~h}$ without removal of the medium. The plates were shaken for $15 \mathrm{~min}$, and absorbance was detected within the range $490-630 \mathrm{~nm}$ on an ELISA reader (ELX800, Bio-Tek Instruments Inc.).

Clonogenic survival assay. The cell survival fraction was determined by a standard colony-forming efficiency assay. Briefly, U251 glioma cells or transfected cells were disaggregated into a single-cell suspension and diluted to a final concentration of $1 \times 10^{3}$ cells $/ \mathrm{ml}$. The cells were then plated onto 6 -well plates and cultured overnight. Then, the cells were subjected to irradiation at doses of 2, 4, 6 and $8 \mathrm{~Gy}$. After irradiation, the plates were incubated at $37^{\circ} \mathrm{C}$ in a $5 \% \mathrm{CO}_{2}$ atmosphere for $\sim 2$ weeks. Prior to colony counting, the cells were washed with PBS, fixed with formalin, stained with crystal violet $(0.1 \% \mathrm{w} / \mathrm{v})$, rinsed with $\mathrm{dH}_{2} \mathrm{O}$, and finally dried. Under a microscope, colonies that contained more than 50 cells were considered to represent survival colonies. The formula used was as follows: colony formation rate $(\mathrm{PE})=$ colony number/cell plating number $\mathrm{x} 100 \%$; survival fraction $(\mathrm{SF})=$ number of colonies formed in response to a certain dose/cell plating number x PE. Data were analyzed, and the cell survival curve was drawn using the GraphPad Prism 5.0 software. Survival assays were repeated in triplicate.
Single-cell gel electrophoresis (neutral comet assay). The single-cell gel electrophoresis assay was carried out with the CometAssay kit (Trevigen, USA) according to the manufacturer's instructions. Briefly, $4 \mathrm{~h}$ after irradiation with 5 Gy of X-rays, U251 single-cell suspensions were washed with PBS and mixed with low-melting agarose (1:10). Next, the cell-agarose mixtures were pipetted onto the comet assay slides. Cell lysis was induced by incubating the mixture at $4^{\circ} \mathrm{C}$ for $3 \mathrm{~h}$, and the treated cells were then electrophoresed for $20 \mathrm{~min}$ at $4^{\circ} \mathrm{C}$. Subsequently, the resolved samples were fixed, and the DNA was visualized by staining with $5 \mu \mathrm{g} / \mathrm{ml}$ Goldview (SBS Genetech, Co., Ltd). Finally, the slides were observed under a confocal laser microscope. Digital fluorescence images were obtained to calculate the percentage of comet tails per 100 cells.

Cell cycle phase and cell apoptosis analysis by flow cytometry. The percentage of cell distribution in the various phases of the cell cycle was detected by flow cytometry. Single-cell suspensions of U251 glioma cells $\left(1 \times 10^{5}\right.$ cells $\left./ \mathrm{ml}\right)$ were washed twice with PBS and fixed with $75 \%$ alcohol. After treatment with $500 \mu \mathrm{l}$ of $1 \mathrm{~g} / \mathrm{l} \mathrm{RNase}$ at $37^{\circ} \mathrm{C}$ for $30 \mathrm{~min}$, the cells were collected and fixed again, followed by staining with propidium iodide (PI) for flow cytometric analysis. The percentage of cells that underwent cell apoptosis was also determined by flow cytometry. Single-cell suspensions of the glioma cells $\left(1 \times 10^{5}\right.$ cells $\left./ \mathrm{ml}, 100 \mu \mathrm{l}\right)$ were added into microcentrifuge tubes and mixed with $5 \mu \mathrm{l}$ of Annexin IV-FITC and $20 \mu \mathrm{g} / \mathrm{ml}$ PI. After 15 min of incubation at room temperature, the percentage of apoptotic cells was determined by flow cytometry.

Detection of caspase-3, -8, and -9. Malignant cells were plated onto 96-well plates at a concentration of 3,000 cells/well and cultured at $37^{\circ} \mathrm{C}$ overnight. After $24 \mathrm{~h}$ of irradiation, caspase-3, -8 , and $-9(100 \mu \mathrm{l} /$ well $)$ were added to the plate. The plates were then shaken for $15 \mathrm{~min}$ at $37^{\circ} \mathrm{C}$, and absorbance was detected at a wavelength range of 490-630 nm using an ELISA reader (ELX800, Bio-Tek Instruments Inc.).

Statistical analysis. SAS 8.1 was used to analyze the experimental data, which are presented as mean \pm SD. The RT-qPCR, CCK-8, caspase expression, comet tail percentage, and flow cytometry data were analyzed by ANOVA. The data from 
A

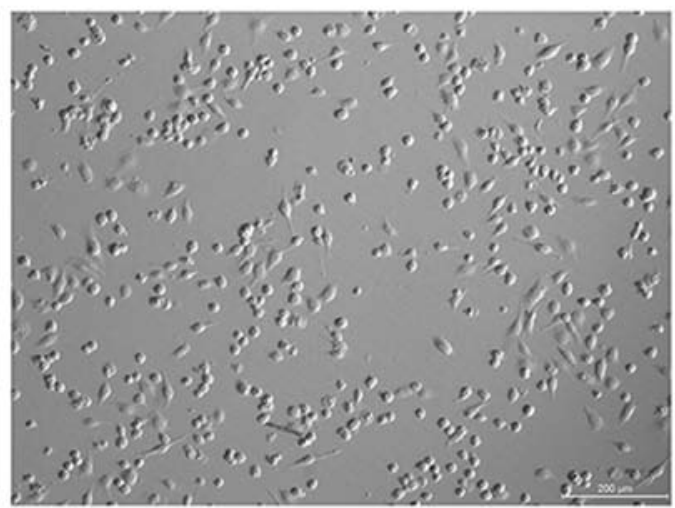

B

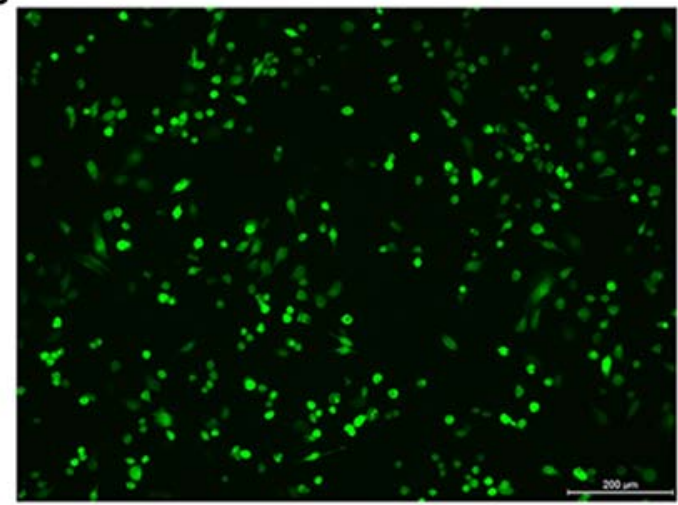

Figure 1. siRNA-ATM lentivirus was transfected into U251 glioma cells, and the efficiency of transfection was nearly $99 \%$. (A) U251 cells were cultured in RPMI-1640 medium before transfection. (B) Transfected U251 cells showing high efficiency of the transfection.

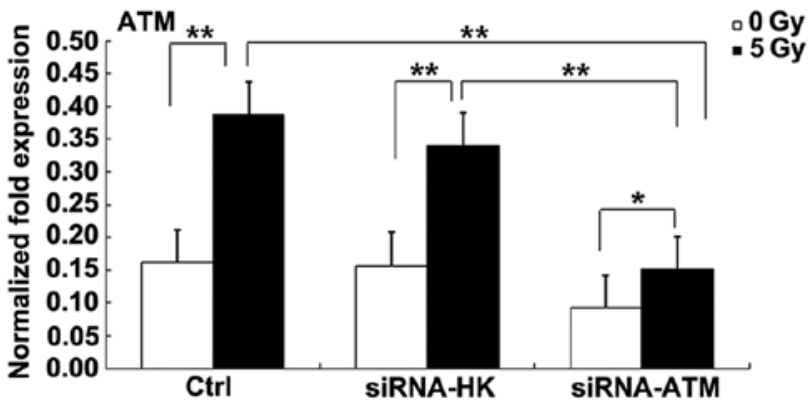

Figure 2. ATM expression after siRNA treatment in U251 cells as determined by RT-qPCR. After 5 Gy irradiation, the gene expression in group A was considerably less than that in groups $\mathrm{C}$ and $\mathrm{N}$. There was no difference between group $\mathrm{A}$ and group $\mathrm{C}$ or $\mathrm{N}$ before radiation treatment. All the experiments were performed in triplicate. Data were analyzed by ANOVA and are presented as mean $\pm \mathrm{SD}$. ${ }^{*} \mathrm{P}<0.05,{ }^{* *} \mathrm{P}<0.01$. Group A, siRNA-ATM; group $\mathrm{C}$, control; group N, siRNA-HK.

the clonogenic survival assay were analyzed using GraphPad Prism 5.0. Changes in tumor volume were analyzed using the Student's t-test. Statistical significance was set at a P-value of $<0.05$.

\section{Results}

Efficiency of cell transfection. siRNA-ATM ${ }^{\text {Puro }}$ and siRNA-HK ${ }^{\text {Puro }}$ lentiviruses were transfected into glioma U251 cells. Under an inverted fluorescence microscope, green fluorescence protein (GFP) was observed to be obviously expressed in the tumor cells, indicating that the efficiency of transfection was nearly 99\% (Fig. 1A and B). Moreover, no obvious dead cells were observed in the medium after resistance selection using puromycin, which also demonstrated the high efficiency of the lentivirus transfection.

Changes in in vitro ATM expression after siRNA treatment. To assess the effect of siRNA-ATM, we examined ATM gene and protein expression in the glioblastoma cells by RT-qPCR and western blotting. In the U251 cells, ATM expression was obviously downregulated after transfection with the lentivirus vector expressing siRNA-ATM. PCR results showed that after exposure to radiation, ATM expression in the $\mathrm{C}$ and $\mathrm{N}$ groups

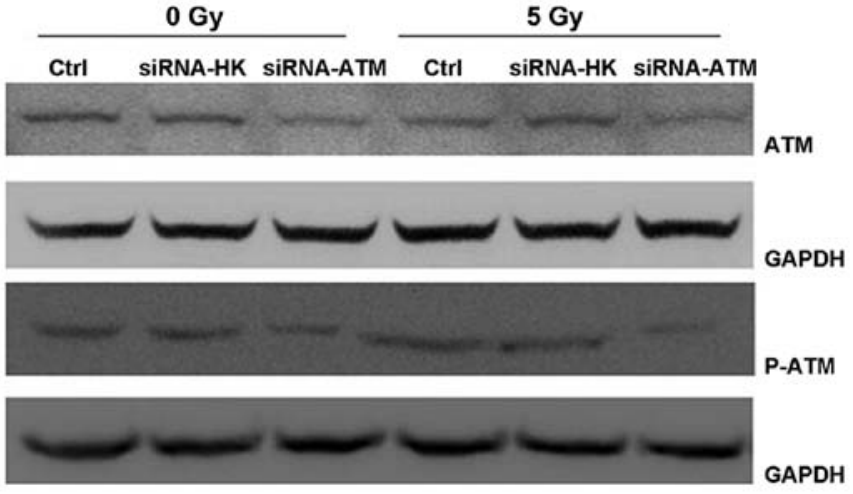

Figure 3. Expression of ATM and phospho(p)-ATM (S1981) after siRNAmediated silencing in U251 cells by western blotting. Total ATM protein expression in group A was not obviously different from that in group $\mathrm{C}$ or $\mathrm{N}$, when a dose of 5 Gy was delivered. Likewise, expression of p-ATM protein in group A was significantly decreased compared with the other groups after irradiation. All the experiments were performed in triplicate. Group A, siRNA-ATM; group C, control; group N, siRNA-HK.

was obviously increased $(\mathrm{P}<0.01)$. However, there was little increase in ATM expression in the A group after irradiation $(\mathrm{P}<0.05)$. Moreover, ATM gene expression was considerably lower in the A group than that noted in the $\mathrm{C}$ or $\mathrm{N}$ group $(\mathrm{P}<0.01)$ (Fig. 2).

Western blotting revealed similar results in the U251 cell line. In both the $\mathrm{C}$ and $\mathrm{N}$ groups, the total level of ATM protein was similar before and after irradiation. p-ATM protein was expressed slightly before irradiation, while its expression was considerably higher after irradiation. In the A group, the amount of total ATM protein was obviously lower after irradiation, but expression of the p-ATM protein was not obviously observed before or after irradiation (Fig. 3). After radiation treatment, the levels of total ATM and p-ATM proteins in group $\mathrm{A}$ were lower than levels in the $\mathrm{C}$ and $\mathrm{N}$ groups (Fig. 3).

Changes in the expression of other radiosensitivity-related genes after transfection of siRNA-ATM lentivirus into glioma cell lines. The expression of other radiosensitivity-related genes, including P53, PCNA and survivin, was also examined by RTq-PCR. After irradiation, the expression of the three genes (P53, PCNA, and survivin) increased to some 

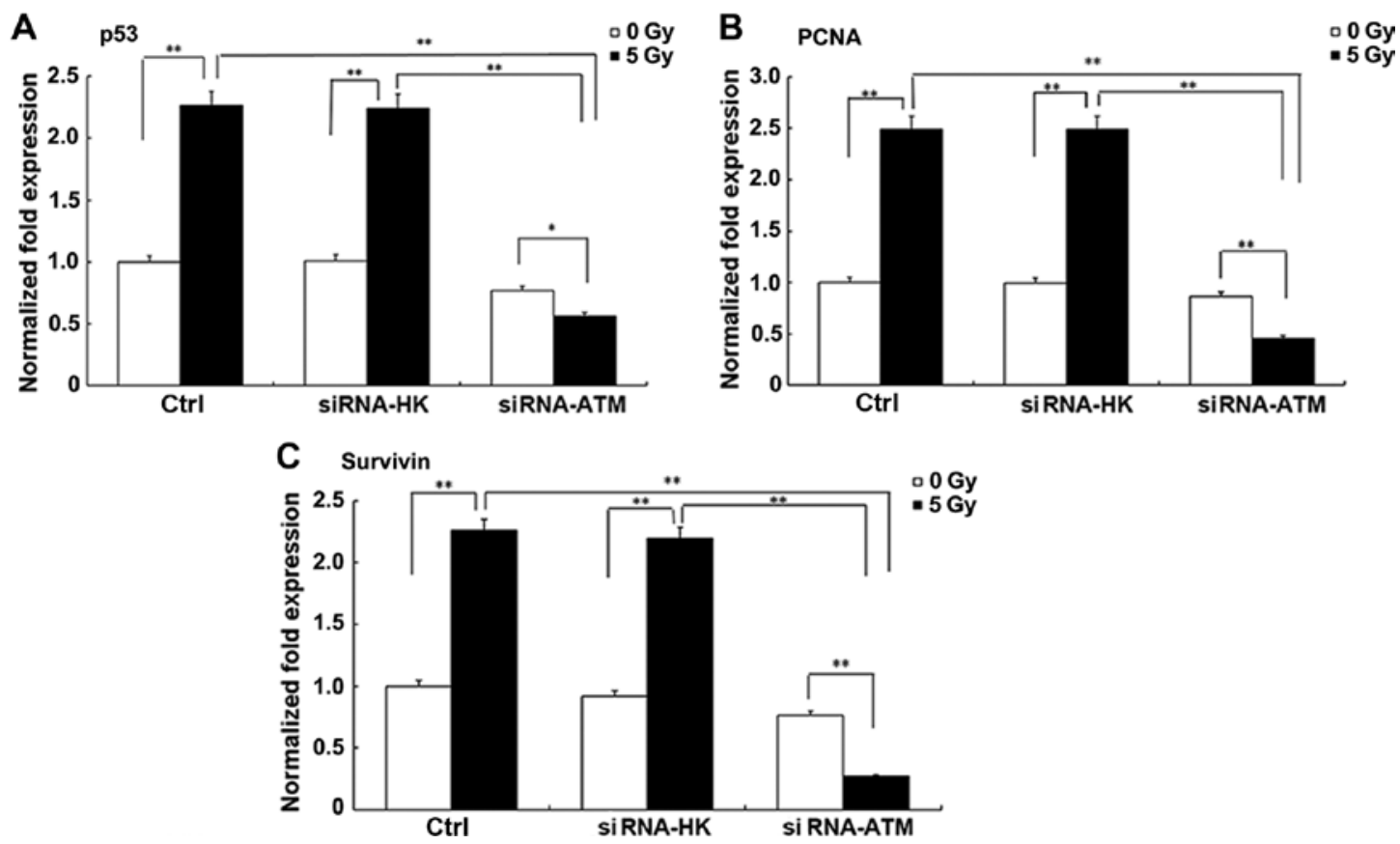

Figure 4. Expression of the radiosensitivity-related genes (A) P53, (B) PCNA and (C) survivin in the U251 cells as determined by RT-qPCR. After irradiation, expression of the three genes was considerably lower in group A than in groups $\mathrm{C}$ and $\mathrm{N}$. There was no obvious difference among the groups before radiation. All the experiments were performed in triplicate. Data were analyzed by ANOVA and are presented as mean $\pm \mathrm{SD}$. ${ }^{*} \mathrm{P}<0.05$, ${ }^{* *} \mathrm{P}<0.01$. Group A, siRNA-ATM; group C, control; group N, siRNA-HK.

degree in the $\mathrm{C}$ and $\mathrm{N}$ groups, but their expression was decreased in the A group $(\mathrm{P}<0.01)$. After irradiation, the lower expression of these genes in the A group was more obvious $(\mathrm{P}<0.01)$ (Fig. 4A-C).

Inhibition of cell proliferation after siRNA-ATM treatment. At 48 and $72 \mathrm{~h}$ after irradiation, cell proliferation in the A group was significantly less than that in the $\mathrm{C}$ and $\mathrm{N}$ groups (Fig. 5) ( $\mathrm{P}<0.01$, A group vs. $\mathrm{N}$ group; $\mathrm{P}<0.05$, A group vs. $\mathrm{C}$ group). Between the two time-points, there was no obvious increase in cell proliferation in the A group. However, cell proliferation in the $\mathrm{C}$ and $\mathrm{N}$ groups showed a mild increase from 48 to $72 \mathrm{~h}$ $(\mathrm{P}>0.05)$.

Clonogenic survival assay of the siRNA-ATM-transfected cell line after irradiation. The number of colonies formed decreased with an increase in the radiation dose in groups A and $\mathrm{N}$, which indicated a dose-dependent relationship (Fig. 6A). At the same dose, the number of colonies in the A group was less than that in the $\mathrm{C}$ and $\mathrm{N}$ groups, while the number was similar in the $\mathrm{N}$ group (Fig. 6B). Microscopic observation after crystal violet staining showed that the colonies formed by cells of the A group were smaller and lesser in number (Fig. 6C), and they further decreased in size and number with an increase in the radiation dose.

Single-cell gel electrophoresis (neutral comet assay). Before irradiation, comet tail formation was not observed in any of the three groups. However, the proportion of comet tails in the A group was elevated after irradiation with 5 Gy X-ray, as compared with that in the $\mathrm{C}$ and $\mathrm{N}$ groups $(\mathrm{P}<0.01)$ (Fig. 7). The results in the $\mathrm{C}$ group were similar to those in the $\mathrm{N}$ group.

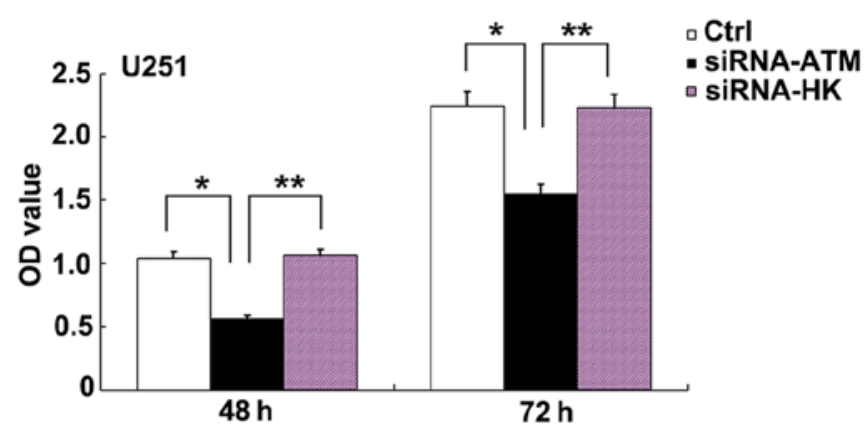

Figure 5. Cell proliferation is inhibited after siRNA-ATM treatment in the U251 cells. At 48 and $72 \mathrm{~h}$ after irradiation, cell proliferation in group A was considerably less than that in groups $\mathrm{C}$ and $\mathrm{N}$. All the experiments were performed in triplicate. Data were analyzed by ANOVA. ${ }^{*} \mathrm{P}<0.05,{ }^{* *} \mathrm{P}<0.01$. Group A, siRNA-ATM; group C, control; group N, siRNA-HK.

Effect of irradiation on cell cycle distribution and cell apoptosis. The percentage of apoptotic cells in group A, particularly those in the later cell cycle stages, was greater than that in groups $\mathrm{C}$ and $\mathrm{N}(\mathrm{P}<0.01)$ (Fig. 8). There was no significant difference in the apoptosis rate between group C and group N. Similarly, the percentage of cells in the $\mathrm{G} 2$ phase in group $\mathrm{A}$ showed an obvious increase compared with groups $\mathrm{C}$ and $\mathrm{N}(\mathrm{P}<0.01)$ (Fig. 9).

Detection of caspase-3, -8 and -9 . The expression levels of caspase-3, -8 and -9 , which are linked to the apoptosis pathway, were higher in group $\mathrm{A}$ than in group $\mathrm{C}$ and $\mathrm{N}$ (caspase-3: $\mathrm{P}<0.05$, group $\mathrm{A}$ vs. group $\mathrm{C} ; \mathrm{P}<0.01$, group $\mathrm{A}$ vs. group $\mathrm{N}$; caspase-8: $\mathrm{P}<0.01$, group A vs. group $\mathrm{C} / \mathrm{N}$; caspase-9: $\mathrm{P}<0.05$, group A vs. group $\mathrm{C} / \mathrm{N})$. No significant difference was found between group $\mathrm{C}$ and $\mathrm{N}$ (Fig. 10A-C). 

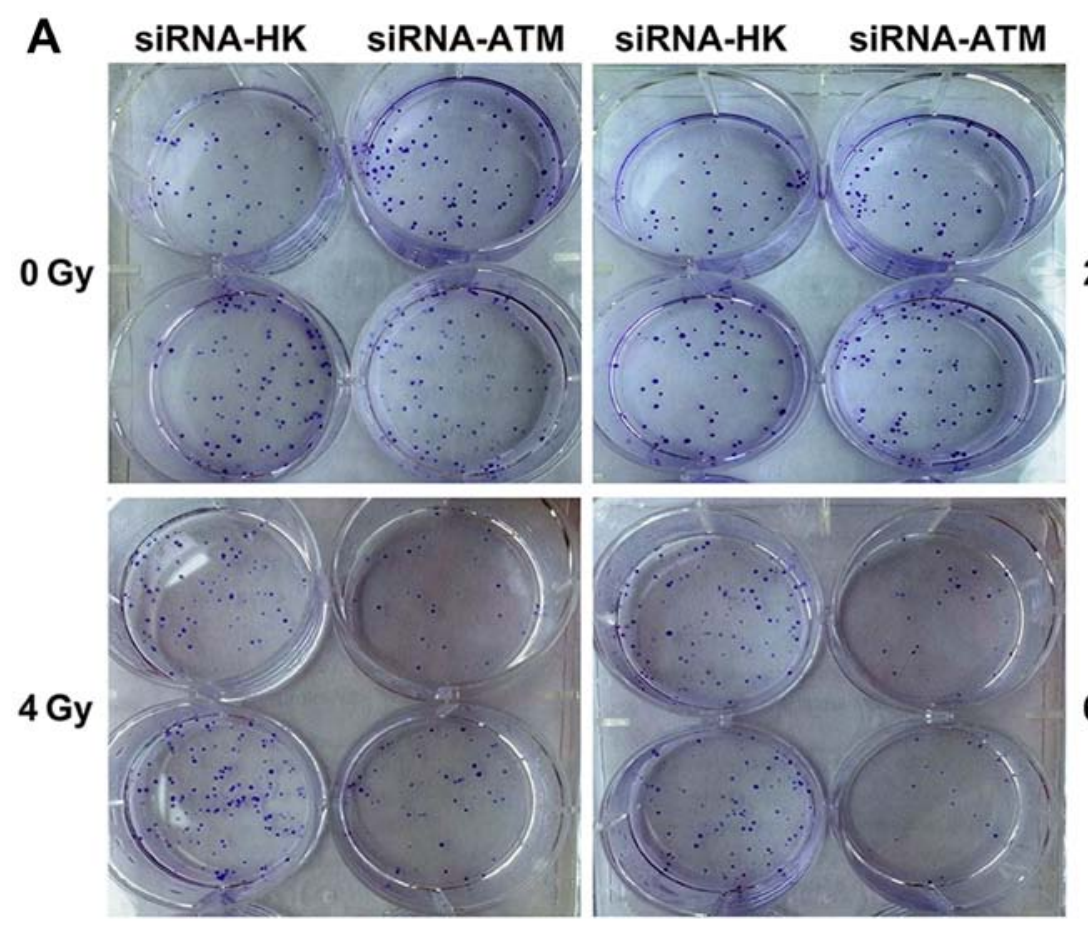

$2 \mathrm{~Gy}$

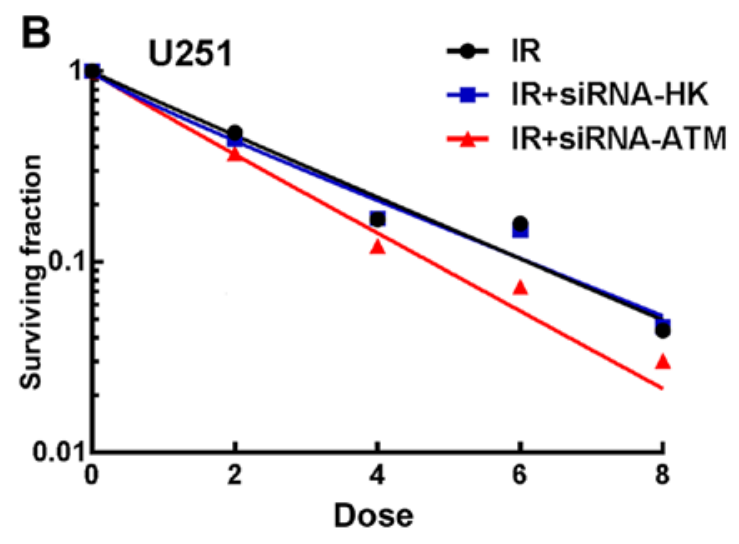

C

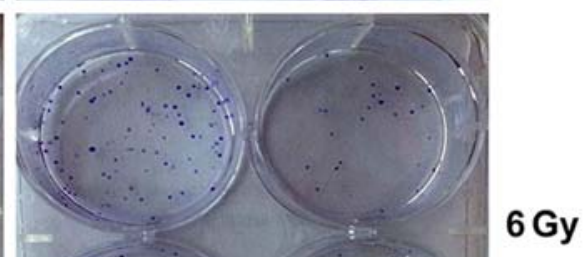

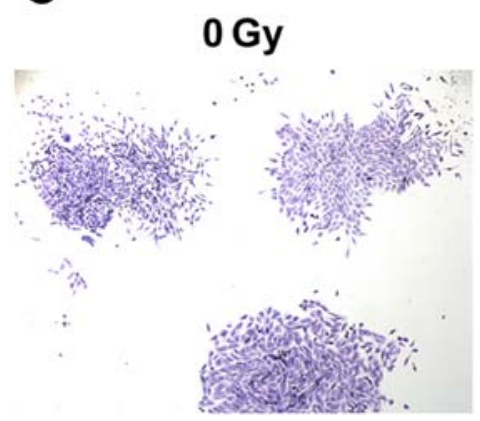

$4 \mathrm{~Gy}$

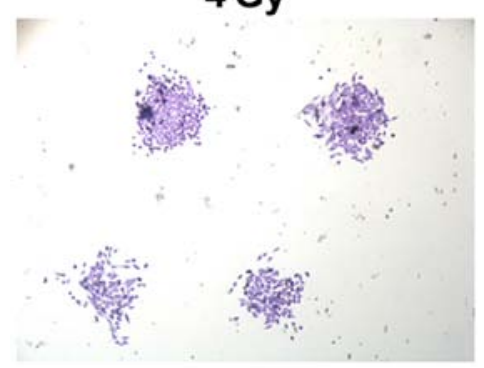

$2 \mathrm{~Gy}$

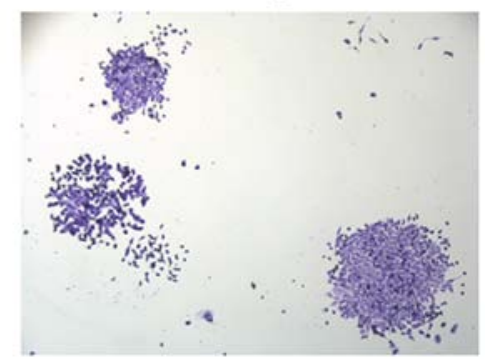

$6 \mathrm{~Gy}$

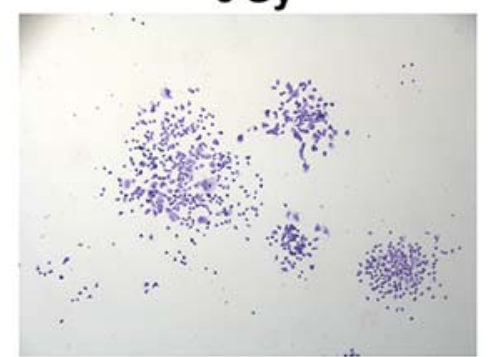

Figure 6. Clonogenic survival assay of siRNA-ATM-transfected U251 cells. (A) Colony formation in groups A and N in the 6-well plates. (B) Survival fraction in the IR+siRNA-ATM group was obviously lower than that in the IR and IR+siRNA-HK group at doses of 2, 4, 6, and 8 Gy. (C) Histopathological analysis showed that the siRNA-ATM-transfected U251 cell colonies were smaller in size and number with an increase in the radiation dose. Group A, siRNA-ATM; group C, control; group N, siRNA-HK. 

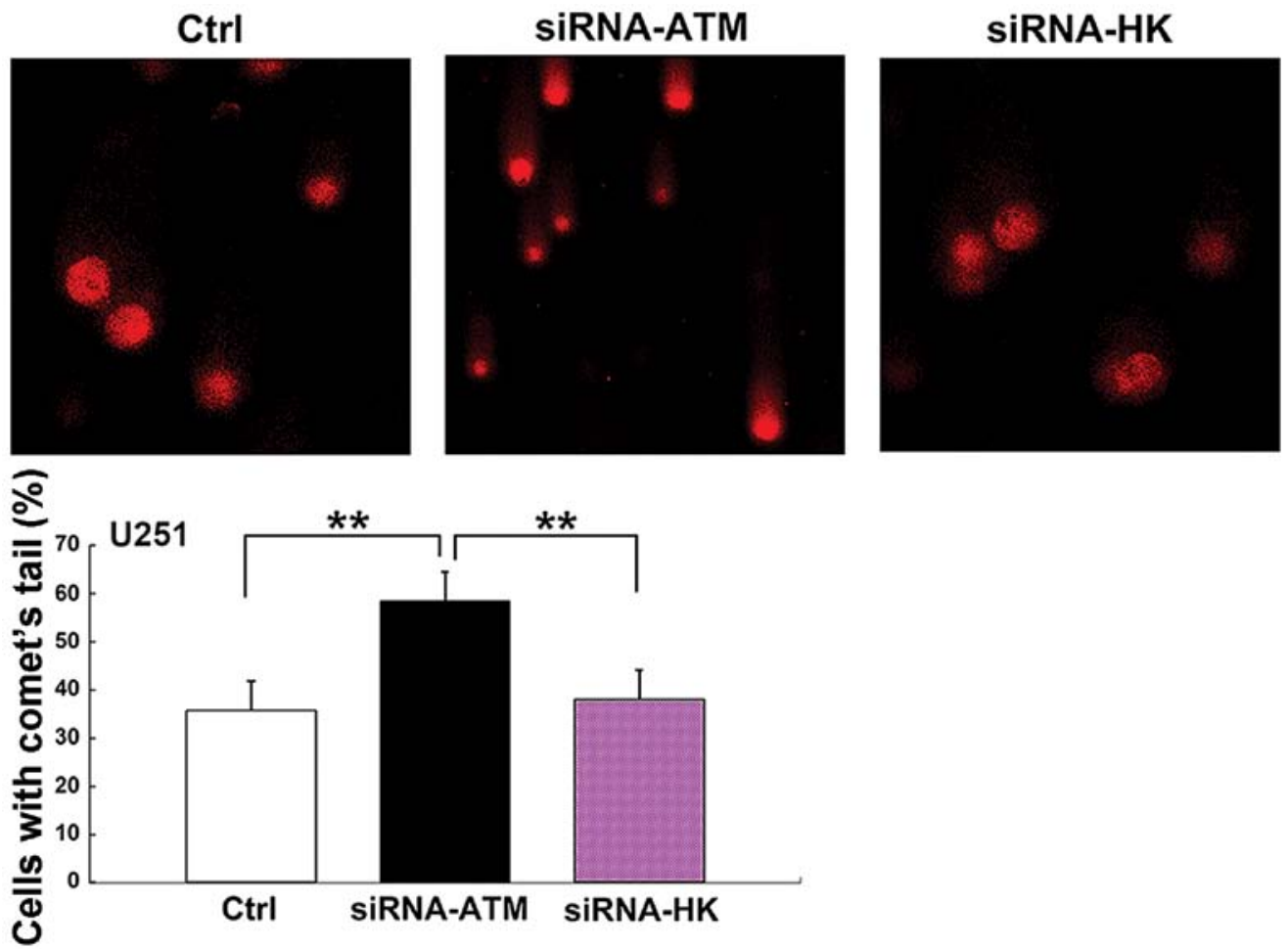

Figure 7. DNA damage in the U251 cells transfected with siRNA against ATM after irradiation. The number of cells with comet tails in group A was higher than that in groups $\mathrm{C}$ and $\mathrm{N}\left({ }^{* *} \mathrm{P}<0.01\right.$, ANOVA). Group A, siRNA-ATM; group C, control; group N, siRNA-HK.
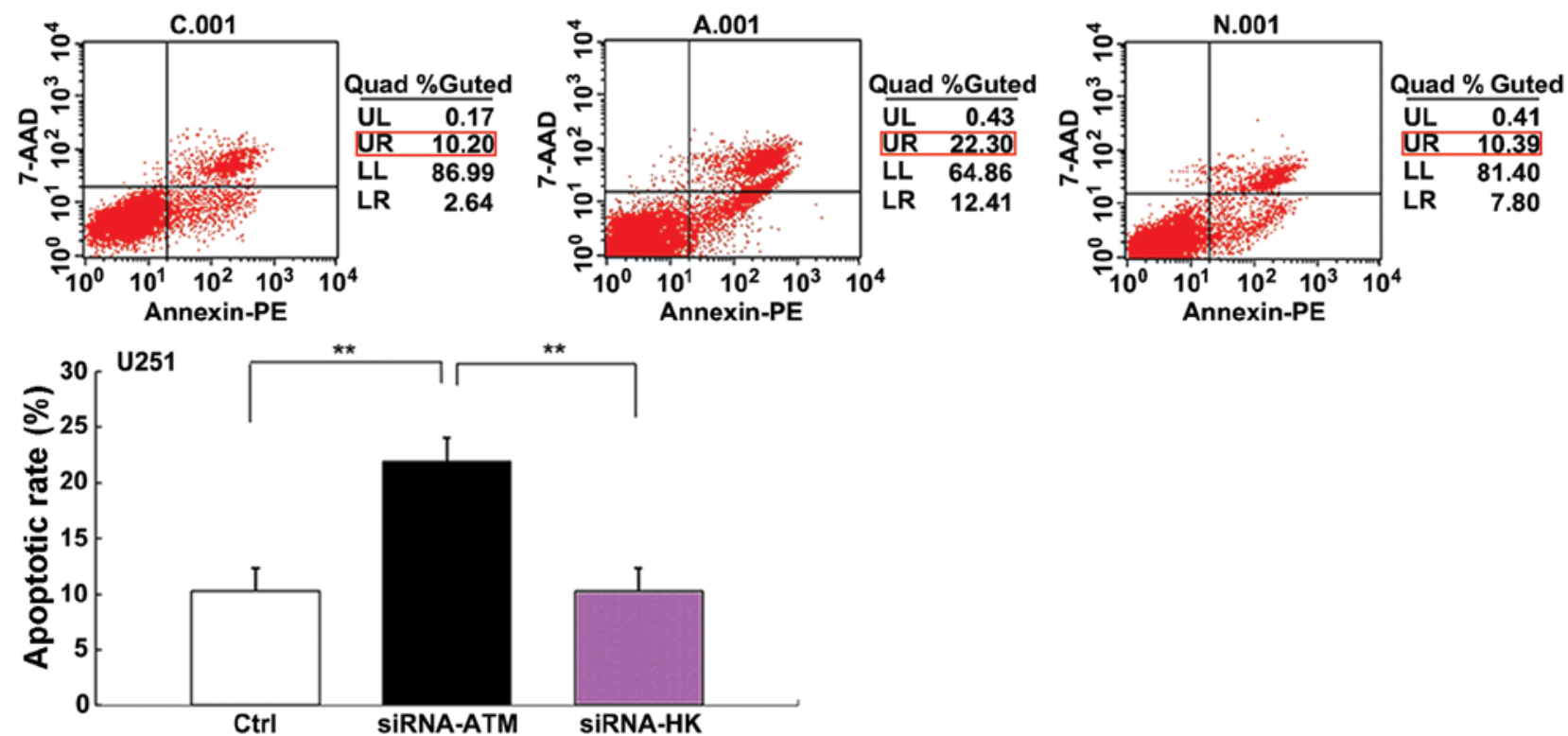

Figure 8. Cell apoptosis in the three groups of U251 cells as determined by flow cytometry. The percentage of cell apoptosis in group A, particularly the percentage of cells in the late apoptotic stage, was greater than that in groups $\mathrm{C}$ and $\mathrm{N}$. Data were analyzed by ANOVA. ${ }^{* *} \mathrm{P}<0.01$. Group A, siRNA-ATM; group $\mathrm{C}$, control; group $\mathrm{N}$, siRNA-HK.

Histopathalogical findings. The histopathological findings in the animal models differed before and after irradiation. Prior to irradiation, the histological features of group A (Fig. 11A) were similar to those of group N (Fig. 11B), and were characterized by nuclear polymorphism, nuclear hyperchromatism, and considerable karyokinesis. However, after irradiation, necrosis and hemorrhage of tumor cells in group A (Fig. 11C) were more obvious than that in group $\mathrm{N}$ (Fig. 11D).
Changes in tumor volume. Within the first to fourth week after implantation, there was no obvious difference in tumor volume between groups $\mathrm{A}$ and $\mathrm{N}$ before treatment with ionizing radiation. The tumor volume was found to be time-dependent: that is, it increased with time. After radiation treatment, the tumor volume in group A decreased while that in group $\mathrm{N}$ remained more or less stable from the first to the fourth week (Fig. 12). The tumor volume in group A 

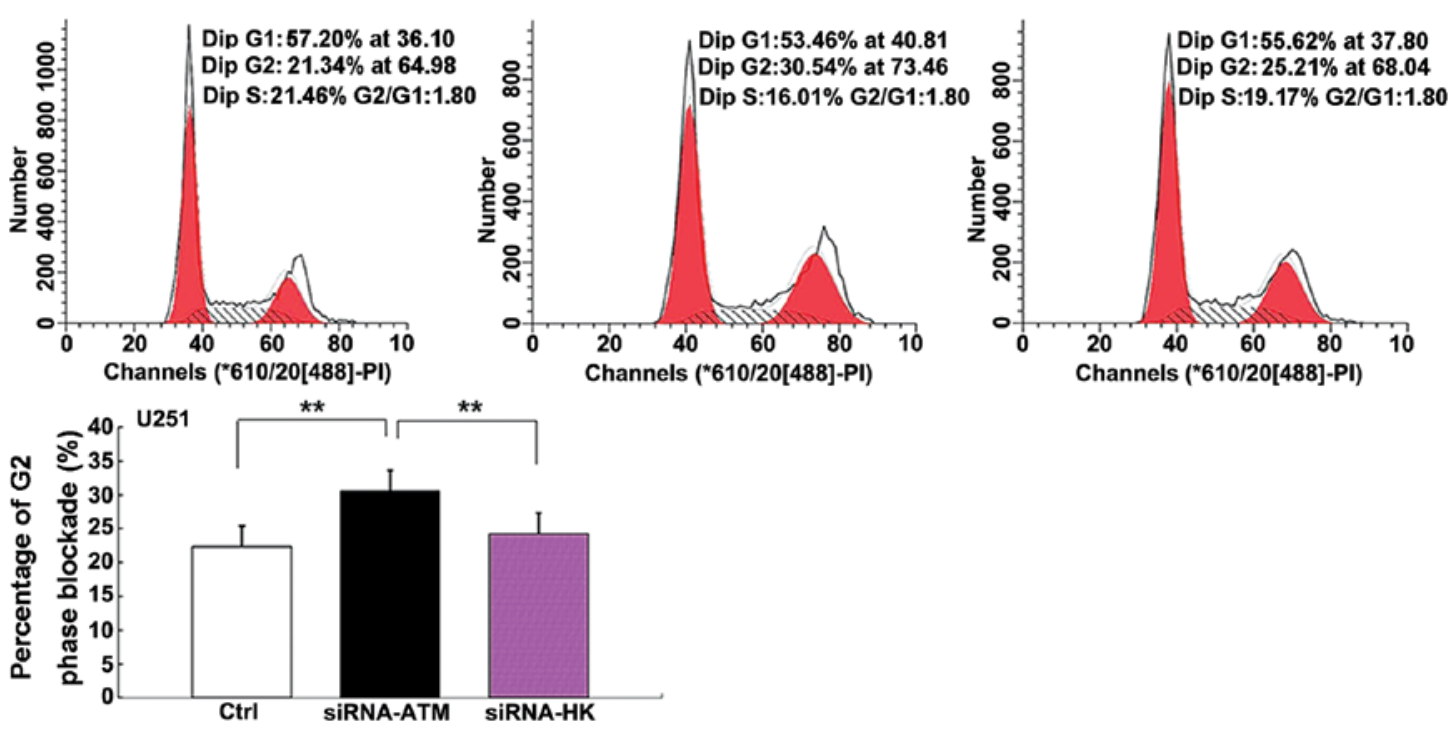

Figure 9. Distribution of cells in the G2 phase under different conditions as determined by flow cytometry. The number of cells in the G2 phase was obviously higher in group A than in groups $\mathrm{C}$ and $\mathrm{N}\left({ }^{* *} \mathrm{P}<0.01\right.$, ANOVA). Group A, siRNA-ATM; group C, control; group N, siRNA-HK.
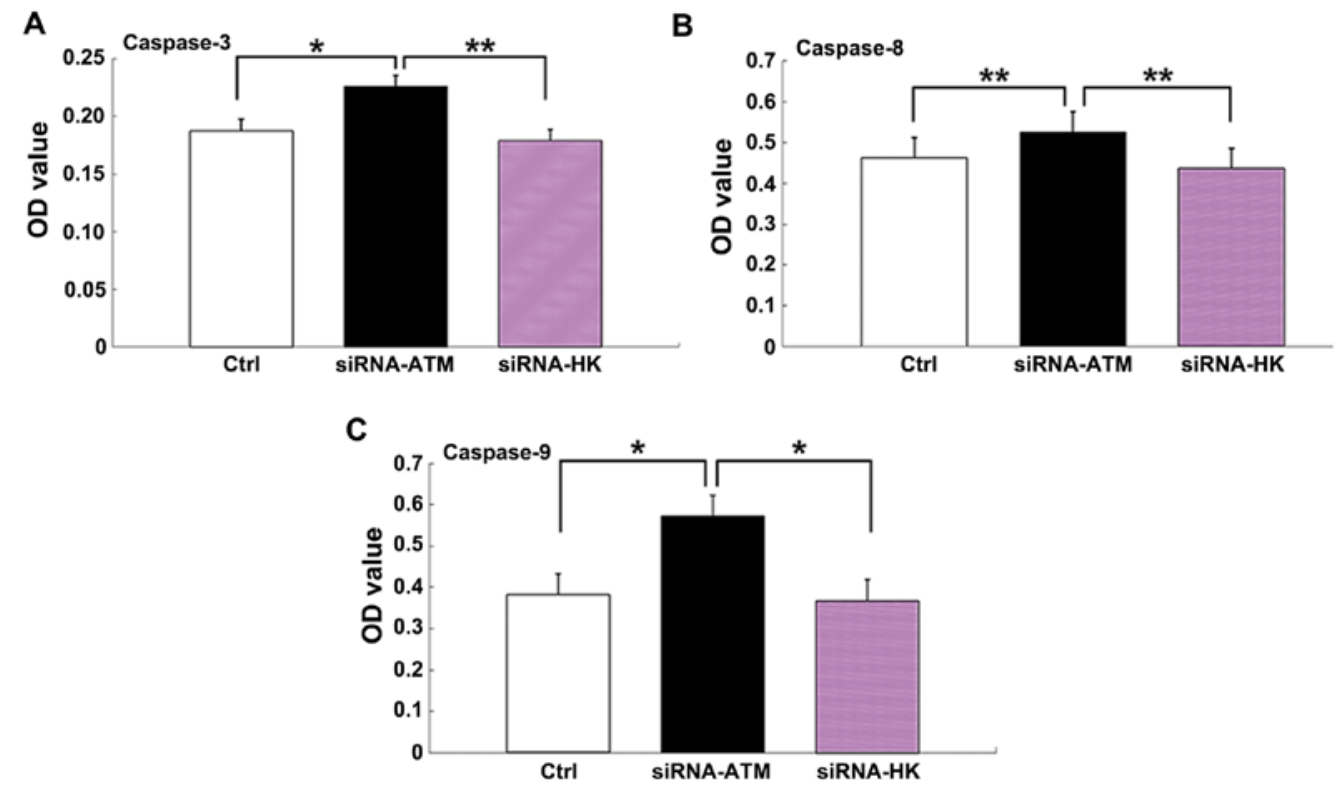

Figure 10. Detection of (A) caspase-3, (B) caspase-8 and (C) caspase-9 expression in the siRNA-ATM U251 cells using the caspase assay kit. The expression of caspase- $3,-8$, and -9 was higher in group $\mathrm{A}$ than in groups $\mathrm{C}$ and $\mathrm{N}\left({ }^{*} \mathrm{P}<0.05,{ }^{* * *} \mathrm{P}<0.01\right.$, ANOVA). Group A, siRNA-ATM; group C, control; group N, siRNA-HK.

was significantly lower than that in group $\mathrm{N}(\mathrm{P}<0.05,2$ and 3 weeks; $\mathrm{P}<0.01,1$ and 4 weeks).

\section{Discussion}

Glioma is a malignant brain tumor that continues to have a poor median survival of about one year. Several researchers have reported that the ATM gene is linked with resistance against radiotherapy, which is associated with the poor prognosis of glioma $(2,8,9)$. For example, Tribius et al (14) reported that ATM was highly expressed after radiation treatment of a glioma cell line. Similarly, in tumors such as cervical cancer and breast cancer, expression of the ATM gene is greatly increased after radiation treatment in tumor cells $(15,16)$. Based on these findings, we hypothesized that lentivirus-mediated silencing of ATM gene expression via the siRNA technique may enhance the radiosensitivity of malignant glioma.

Although gene interference suppressed ATM gene expression, it was not completely effective, and failed to result in the control of the downstream pathway by ATM imperfect retardant. Therefore, in order to ensure effective gene silencing, gene knockdown should be considered to further repress the related signal pathway, as it may enhance the radiosensitivity of gliomas. For instance, some scholars found that $\mathrm{ATM}^{-1-}$ mice had better survival than $\mathrm{ATM}^{-/+}$mice, which indicates that ATM is responsible for therapy resistance (6).

ATM kinase inhibitors have been the subject of research on gliomas during recent years $(1,7,13)$. However, there are 
A

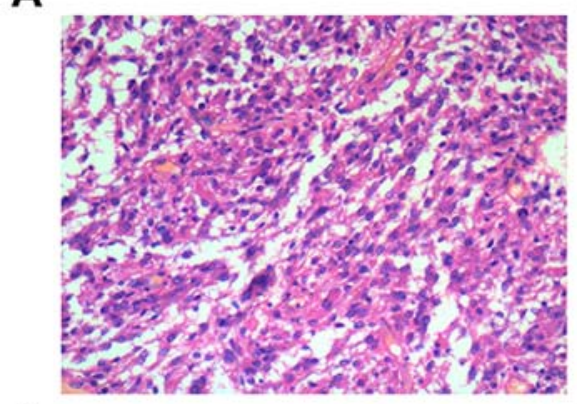

C

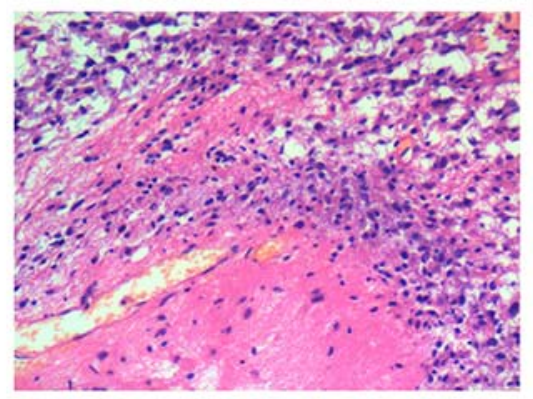

B

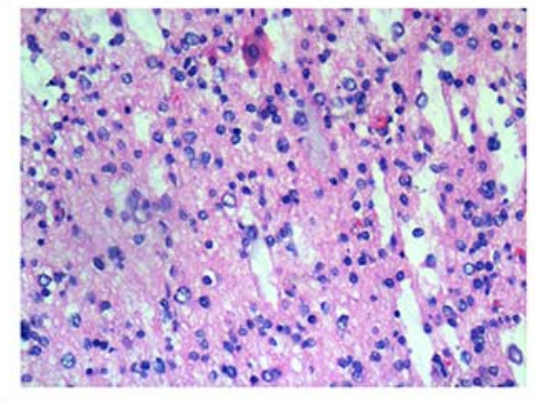

D

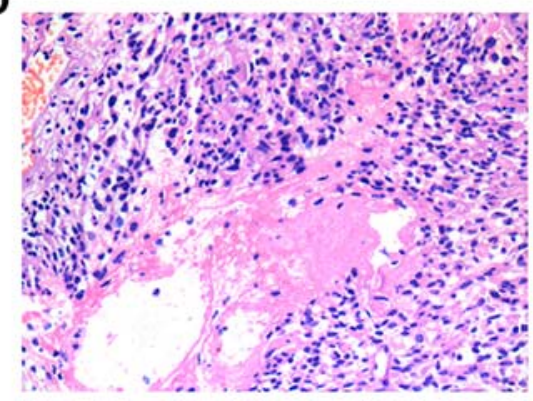

Figure 11. Histopathalogical findings in the siRNA-ATM and siRNA-HK U251 animal models treated with 5 Gy radiation. (A and B) Before radiation, there was no obvious difference in the pathological characteristics between group A and N. (C and D) Necrosis and hemorrhage of tumor cells in group A (C) after irradiation increased obviously compared with group N (D). Group A, siRNA-ATM; group C, control; group N, siRNA-HK.

still many limitations: there is no effective delivery system for administration in cephalic regions; the pharmacological dose for effective in vivo therapy is not clear; and possible harmful effects on the brain are also not clear (7).

In our study, genes related to radiosensitivity (P53, survivin, and PCNA) identified as downstream genes of ATM (17-19), were analyzed by RT-qPCR. The results indicated that P53, survivin, and PCNA were indeed involved in the repair pathway and play a role in the radiosensitivity of glioma cells. These findings are consistent with those of the CCK- 8 and clone formation assay, in which proliferation was also found to be decreased in response to ATM silencing.

Our study found that damage to glioma tumor cells was obviously enhanced by ionizing radiation after the ATM gene was silenced by the siRNA technique. Compared to the control group, the survival curve of group A showed a significant decline, and the number of damaged cells, i.e. the cleavage of double-stranded DNA, in the comet tail assay was obviously increased. All these results verify that the tumor responded to radiation and that radiosensitivity was enhanced after silencing of the ATM gene. The CCK-8 findings showed high expression of ATM after radiation treatment in the control cells, which was considered to be responsible for the repair of damaged cells and maintaining cell proliferation. However, suppression of the ATM gene resulted in a decrease in cell proliferation as a result of slowing down of the cell repair mechanism. However, changes in cell proliferation in relation to time need to be explored in the future. Intriguingly, Moschos et al (20) reported contrasting results when malignant melanoma cells were transfected with siRNA against ATM. According to them, the hyperpigmentation gene may play an important role in the radiosensitivity of melanoma, which could explain their findings.

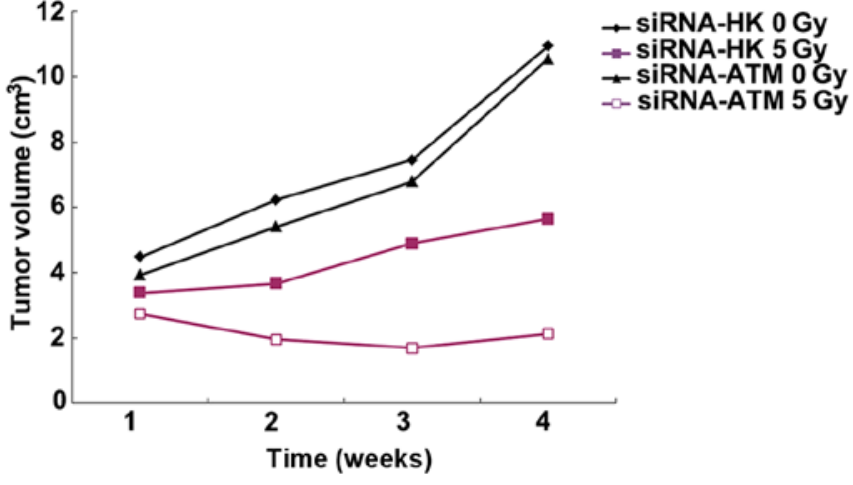

Figure 12. Growth curve of changes in tumor volume in the siRNA-ATM and siRNA-HK mouse models. After radiation treatment, the tumor volume in group A decreased while that in group $\mathrm{N}$ remained the same. Group A, siRNA-ATM; group C, control; group N, siRNA-HK.

In our study, a higher percentage of apoptosed cells were in the late stage than in the early stage. Therefore, another mechanism related to the repair of damaged cells may play an important role after suppression of the ATM gene. After irradiation, expression of the ATM gene increased with time and resulted in a corresponding decline in the amount of repaired cells and increase in the amount of damaged cells. This also explains why a higher number of cells were in the late apoptotic stage than in the early apoptotic stage. The percentage of cells in the G2 phase of the cell cycle was higher in the siRNA-ATM treated group than in the control group, which implies that irradiated tumor cells which were treated with siRNA-ATM performed slow self-repairing.

In addition, we investigated changes in the apoptosis pathway. It is well known that the caspase family plays a role in apoptosis, and that caspase- 8 and caspase- 9 in 
particular are involved in the initiation of apoptosis while caspase 3 plays a key role in apoptosis (21). We found that the expression of caspase-3, caspase-8, and caspase- 9 increased in radiation-treated siRNA-ATM tumor cells. The results demonstrated that silencing of ATM could activate the apoptosis pathway, followed by the enhancement of cell apoptosis and radiosensitivity. On the contrary, Liu et al (22) reported that siRNA against ATM not only directly inhibits caspase- 3 activity but also inhibits caspase- 8 activity during TNF- $\alpha$-induced apoptosis in HeLa cells. We think that the findings may differ according to the type of tumor.

To the best of our knowledge, there is less reported in vivo research on the role of ATM. Here, we verified the in vitro findings under in vivo conditions. After irradiation, the tumor volume decreased and the growth curve was slower than before in the siRNA-ATM-transfected animal models. The results are consistent with the histopathological findings; in other words, hemorrhage and necrosis of tumor cells in the siRNA-ATM-transfected group were greater and resulted in a decrease in tumor volume. However, there was no significant difference in the animal models, which may be related to the short observation period and inefficient elimination of the irradiated tumor. Therefore, the treatment effect needs to be assessed over a longer observation period. Moreover, there are certain limitations with regard to establishment of the glioma model and the side effect of radiation on adjacent tissues. We need to further explore the optimal experimental conditions.

In conclusion, siRNA-ATM transfection in glioma cells resulted in a decline in cell proliferation, colony formation rate and survival and an increase in cell apoptosis, the number of cells in the G2 phase, and the proportion of comet tails. Therefore, we inferred that silencing of the ATM gene via the siRNA technique could enhance the radiosensitivity of glioma cells, which could improve the therapeutic effect of radiation and prolong patient survival. Most of the research in this field has provided similar evidence $(1,2,9)$.

\section{Acknowledgements}

We would like to thank the State Key Laboratory of Ultrasound Engineering in Medicine Co-founded by Chongqing and the Ministry of Science and Technology for providing the lab. We acknowledge grant support from the National Natural Science Foundation of China (no. 81172387) and the Natural Science Foundation of Chongqing (CSTC2011BB5119).

\section{References}

1. Biddlestone-Thorpe L, Sajjad M, Rosenberg E, Beckta JM, Valerie NC, Tokarz M, Adams BR, Wagner AF, Khalil A, Gilfor D, et al: ATM kinase inhibition preferentially sensitizes p53-mutant glioma to ionizing radiation. Clin Cancer Res 19: 3189-3200, 2013.

2. Wang SC, Wu CC, Wei YY, Hong JH and Chiang CS: Inactivation of ataxia telangiectasia mutated gene can increase intracellular reactive oxygen species levels and alter radiation-induced cell death pathways in human glioma cells. Int J Radiat Biol 87: 432-442, 2011 .

3. Lee JH and Paull TT: ATM activation by DNA double-strand breaks through the Mre11-Rad50-Nbs1 complex. Science 308: $551-554,2005$.
4. Shiloh Y: ATM and related protein kinases: safeguarding genome integrity. Nat Rev Cancer 3: 155-168, 2003.

5. Jackson SP: Sensing and repairing DNA double-strand breaks. Carcinogenesis 23: 687-696, 2002.

6. Squatrito M, Brennan CW, Helmy K, Huse JT, Petrini JH and Holland EC: Loss of ATM/Chk2/p53 pathway components accelerates tumor development and contributes to radiation resistance in gliomas. Cancer Cell 18: 619-629, 2010.

7. Vecchio D, Daga A, Carra E, Marubbi D, Baio G, Neumaier CE, Vagge S, Corvò R, Pia Brisigotti M, Louis Ravetti J, et al: Predictability, efficacy and safety of radiosensitization of glioblastoma-initiating cells by the ATM inhibitor KU-60019. Int J Cancer 15: 479-491, 2014.

8. Golding SE, Rosenberg E, Adams BR, Wignarajah S, Beckta JM, O'Connor MJ and Valerie K: Dynamic inhibition of ATM kinase provides a strategy for glioblastoma multiforme radiosensitization and growth control. Cell Cycle 11: 1167-1173, 2012.

9. Gil del Alcazar CR, Hardebeck MC, Mukherjee B, Tomimatsu N, Gao X, Yan J, Xie XJ, Bachoo R, Li L, Habib AA, et al: Inhibition of DNA double-strand break repair by the dual PI3K/mTOR inhibitor NVP-BEZ235 as a strategy for radiosensitization of glioblastoma. Clin Cancer Res 20: 1235-1248, 2014.

10. Zhou W, Sun M, Li GH, Wu YZ, Wang Y, Jin F, Zhang YY, Yang L and Wang DL: Activation of the phosphorylation of ATM contributes to radioresistance of glioma stem cells. Oncol Rep 30: 1793-1801, 2013.

11. Guha C, Guha U, Tribius S, Alfieri A, Casper D, Chakravarty P, Mellado W, Pandita TK and Vikram B: Antisense ATM gene therapy: a strategy to increase the radiosensitivity of human tumors. Gene Ther 7: 852-858, 2000.

12. Chuah TL, Walker DG, Wei M, Scott S and Lavin MF: Approaches to sensitizing glioblastoma to radiotherapy: use of lentiviral vectors. Int J Oncol 40: 1963-1969, 2012.

13. Nadkarni A, Shrivastav M, Mladek AC, Schwingler PM, Grogan PT, Chen J and Sarkaria JN: ATM inhibitor KU-55933 increases the TMZ responsiveness of only inherently TMZ sensitive GBM cells. J Neurooncol 110: 349-357, 2012.

14. Tribius S, Pidel A and Casper D: ATM protein expression correlates with radioresistance in primary glioblastoma cells in culture. Int J Radiat Oncol Biol Phys 50: 511-523, 2001.

15. Li W, Jian W, Xiaoping X, Yingfeng L, Tao X and Xiaoyan X: Enhanced radiation-mediated cell killing of human cervical cancer cells by small interference RNA silencing of ataxia telangiectasiamutated protein. Int J Gynecol Cancer 16: 1620-1630, 2006.

16. Bernstein JL, Haile RW, Stovall M, Boice JD Jr, Shore RE, Langholz B, Thomas DC, Bernstein L, Lynch CF, Olsen JH, et al; WECARE Study Collaborative Group: Radiation exposure, the ATM Gene, and contralateral breast cancer in the women's environmental cancer and radiation epidemiology study. J Natl Cancer Inst 102: 475-483, 2010.

17. Poosarla C, Ramesh M, Ramesh K, Gudiseva S, Bala S and Sundar M: Proliferating cell nuclear antigen in premalignancy and oral squamous cell carcinoma. J Clin Diagn Res 9: ZC39-ZC41, 2015.

18. Yang M, Zhai X, Xia B, Wang Y and Lou G: Long noncoding RNA CCHE1 promotes cervical cancer cell proliferation via upregulating PCNA. Tumour Biol 36: 7615-7622, 2015.

19. Tamm I, Wang Y, Sausville E, Scudiero DA, Vigna N, Oltersdorf T and Reed JC: IAP-family protein survivin inhibits caspase activity and apoptosis induced by Fas (CD95), Bax, caspases, and anticancer drugs. Cancer Res 58: 5315-5320, 1998.

20. Moschos SJ, Dodd NR, Jukic DM, Fayewicz SL, Wang X and Becker D: Suppressing the high-level expression and function of ATM in advanced-stage melanomas does not sensitize the cells to ionizing radiation. Cancer Biol Ther 8: 1815-1825, 2009.

21. Sahu U, Sidhar H, Ghate PS, Advirao GM, Raghavan SC and Giri RK: A novel anticancer agent, 8-methoxypyrimido[4',5':4,5] thieno(2,3-b) quinoline-4(3h)-one induces neuro 2 a neuroblastoma cell death through p53-dependent, caspase-dependent and -independent apoptotic pathways. PLoS One 8: e66430, 2013.

22. Liu L, Yim H, Choi JH, Kim ST, Jin Y and Lee SK: ATM kinase promotes both caspase- 8 and caspase-9 activation during TNF- $\alpha$-induced apoptosis of HeLa cells. FEBS Lett 588: 929-935, 2014. 